\title{
Web-Based Academic Potential Test Information System Case Study: Faculty of Teacher Training and Eatucation Victory University of Sorong)
}

\author{
Natasya V. Leuwol ${ }^{1}$, Melda Agnes Manuhutu ${ }^{2}$, Muhammad Z. Sirajuddin ${ }^{3}$
}

Faculty of Computer Science, Victory University of Sorong

Inatasya.leuwol@gmail.com,

${ }^{2}$ melda.a.manuhutu@gmail.com, ${ }^{3}$ mzsirajuddin@student.unvicsorong.ac.id

\begin{abstract}
Academic Potential Test (TPA) is a test used to measure a person's ability level. At the Faculty of Teacher Training and Education (FKIP) Victory University, Sorong, TPA was held before the Field Experience Program (PPL) where the implementation was still manual, namely the test was carried out in writing using paper and corrections by the lecturer. It takes a long time to correct and uses a lot of paper. The purpose of this research is to design a Web-Based Academic Potential Test Information System. System development used the prototype method. This research used the PHP programming language, the database is built using MySQL. The result of this study is that this webbased academic potential test information system helps FKIP in conducting online academic potential tests, where this test can be taken anywhere and can see the results directly after taking the test.
\end{abstract}

Keywords: System, Information, Academic Potential Test

\section{Introduction}

Academic Potential Test also known as TPA is a test designed to measure the level of ability or potential of a person in a scientific or academic field. TPA is a very important test and is needed by many people because it is required in several important matters of selection in the world of work, and even more importantly, TPA is set as one of the absolute requirements in the world of education. The benefits of TPA are as a description of students to achieve success in the subjects taken at school, assessing students' ability to analyze and solve a problem, and as a predictor of student success in learning at school [1]. TPA is the Indonesian version of the Graduate Record Examination or GRE. The models, materials, and fields tested in the TPA also mostly refer to the GRE. This is important to do to ensure that education in Indonesia is progressing. Education is a benchmark for national development therefore every Indonesian citizen has the same responsibility to follow the educational process, in order to contribute thoughts to the development of Indonesia [2].

The Faculty of Teacher Training and Education (FKIP) at Victory University of Sorong is a teaching faculty that has a vision to organize teacher education in order to produce educators who are high in faith, professional and competent in their fields. In order to produce professional educators, one of the compulsory courses that a student must take is the PPL (Field Experience Program) course. Basically, the students are required to take a TPA exam and debriefing activities before taking the PPL. This test is used to determine the ability of students in speaking, accuracy and logical thinking. Academic potential test is a test that is held to measure the possibility of student success in undergoing the subjects that will be studied in class [3].

The TPA has been carried out manually in FKIP, where in practice students come to campus, they are collected in a classroom to work on test questions on paper with a time of 100 minutes with a total of 20 questions with details of 15 multiple choice questions 
and 5 essay questions. At the end of the test, the answers willobe lecturer. This process requires a place, the use of paper and testresutts that needutwowait for the results of the correction. The implementation of the TPA at the FKIP of $y_{i: \text { ictory }}$ University of Sorong needs to be improved and adjusted to the current condition of Covid-19 pandemic. The limited space for movement due to meeting restrictions and social distancing requires FKIP Victory University of Sorong to improve itself in improving its quality while ensuring that every academic activity can run well. In the current era of globalization, the development of information systems, there are many information systems in organizations that want to reach the information system stage quickly, relevantly and accurately [4].

The design of a website-based Academic Potential Test Information System at the Faculty of Teacher Training and Education, Victory University of Sorong can be used to solve this problem. This information system will ensure that TPA can be carried out anywhere directly and efficiently. It has been proven that web/online-based information systems/information technology have made it easier to implement the academic administration system in universities [5], [6], [7].

\section{Research Methodology}

\subsection{Information System}

An information system is a system within an organization that brings data management needs, supports operations, is managerial and strategic in activities of an organization or agency and provides reports for certain parties [8]. Information System is a system within the organization that brings together the daily transaction processing needs that support the managerial functions of the organization's operations [9]. Hence, it can be concluded that the information system is a system used by organizations that function to manage data and support operations to provide certain reports.

\subsection{Academic Potential Test}

Academic Potential Test (TPA) is a test that aims to determine a person's talents and abilities in the scientific (academic) field. This test is also often associated with intelligence. The Academic Potential Test is also identical to the GRE (Graduate Record Examination) test which has become an international standard. In this verbal test, the ability and language skills, both vocabulary mastery, grammar, and the ability to understand the text of the test takers are tested with various tests. Quantitative tests are intended to measure the ability to digest, analyze, and draw conclusions as well as measure the level of intelligence, accuracy, as well as a person's accuracy, in looking at problems in an integrated, systematic, and comprehensive manner from various directions / angles / aspects / sides.

\subsection{Website}

The web is an application that contains multimedia documents (text, images, sound, animation, video) in it that uses the HTTP (Hypertext Transfer Protocol), and to access it needs a browser [10]. Furthermore, the web is the entire web page contained in a domain that contains information [11].

\subsection{Database}

Database is a container or a gathering place for tables that have attributes and data. The tables in the database are interconnected with each other, thus forming an information that users need. The presentation of information is processed using applications or computer programs [12]. In this system, the database is built using MySQL and the programming language used is PHP. 


\subsection{System Development Model}
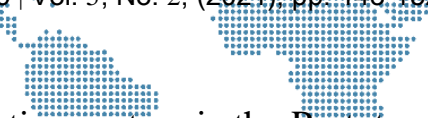

"...:

The method used by the author in developing this informationsystem is the Pitototype Method. This is based on the reason that this method can simplexte and speed up design [13], [14] where the application system can be applied directly without waiting for the entire system to complete. The following is a chart of the prototype method as follows:

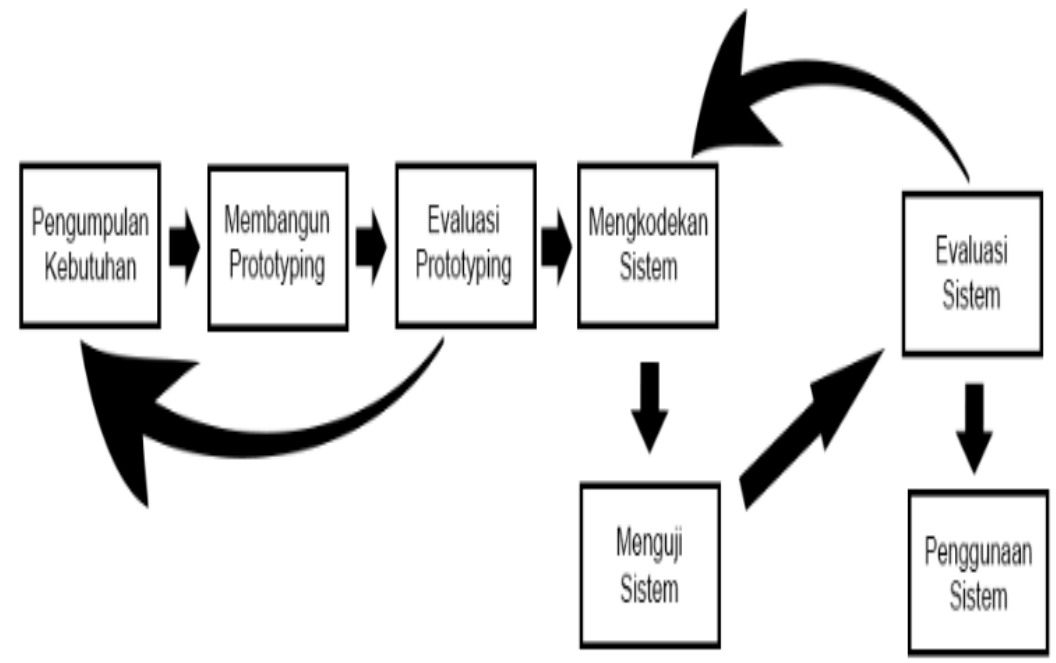

Figure 1. Prototype Method

In this method, there are several stages of system development, which can be explained as follows:

a) Collection of Needs

This stage collects information on problems and needs from the Faculty of Teacher Training and Education, Victory University, Sorong

b) Build Prototyping

This stage makes input and output formats generated by the system. The format is designed using the Adobe Photoshop application.

c) Evaluation of Prototyping

This stage is carried out whether the prototyping that has been built is in accordance with the needs. Then the prototyping will be revised and repeat the previous steps.

But if it is appropriate then do the next step.

d) Coding System

At this stage the agreed prototyping is translated into the PHP programming language.

e) Testing the system

The system is running well or there are still parts that need to be repaired. Testing this system is done by Black Box Testing.

f) System Evaluation

This stage evaluates the system that has been made as desired. If not, it will return to stages 4 and 5 . If yes, then do the next step.

g) Using the System

This stage is the final stage, where the system is ready for use. 


\subsection{Flowchart System}
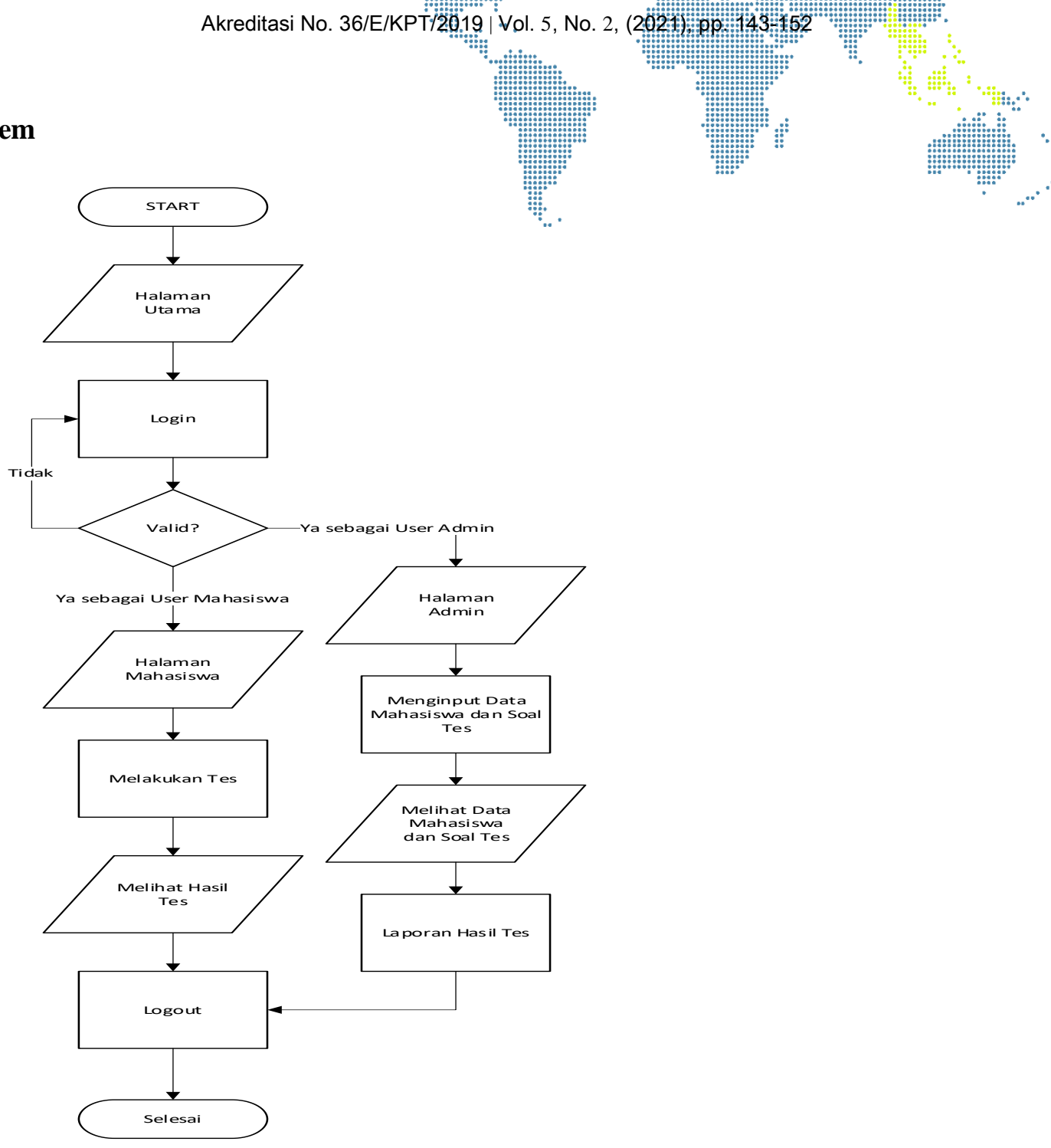

Figure 2. System Flowchart

A flowchart is a chart that shows the results in a program or system procedure logically. Flowcharts are used primarily for communication aids and for documentation. First process, the user will open the system then before entering the menu the user first logs in, if the user inputs the wrong username and or password, she/he will return to the login page, if the user successfully logs in, she/he will enter the student or admin page. On the student user page, where this user is a student who can take the TPA test, then after completing the test, you can see the results immediately. On the admin user page, where the admin can manage student data, then can input questions, and can also view test results reports. After all users have finished, all users can logout from the system.

\section{Result and Discussion}

\subsection{Students' Display}

\subsubsection{Initial Display}

The main view is the initial display when the system is accessed. Students can login by filling in the correct username and password in the login form provided. 


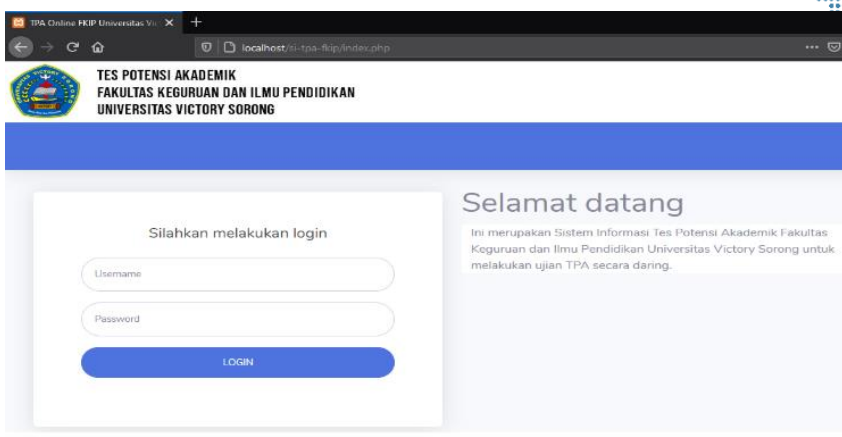

Figure 3. Initial Display

\subsubsection{Dashboard Menu}

The dashboard menu is the display when the student successfully logs in. There is an option to take a test and view test results.

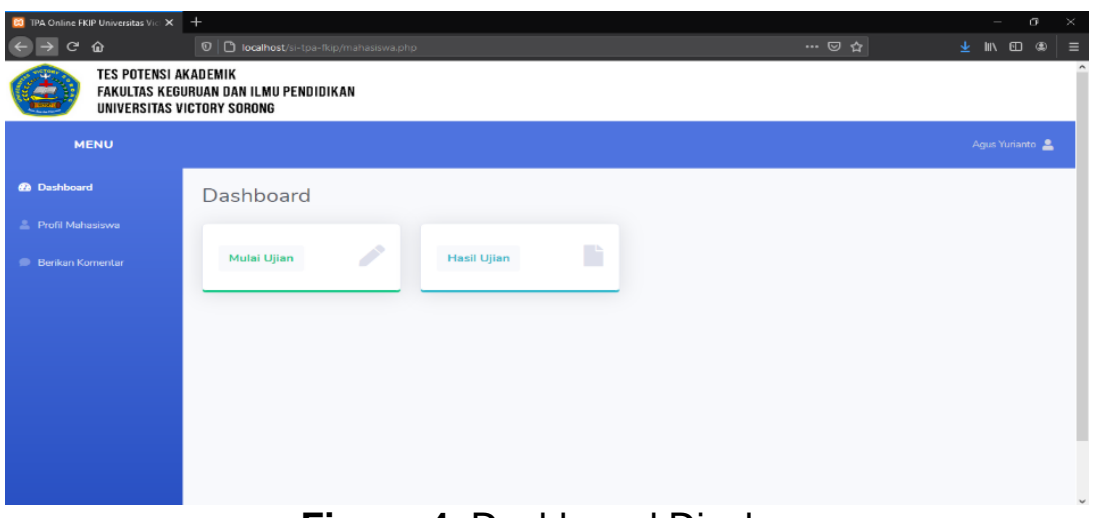

Figure 4. Dashboard Display

\subsubsection{Student Profile Menu}

The student profile menu is the display when a student accesses the student profile menu. Information on student profile data is presented.

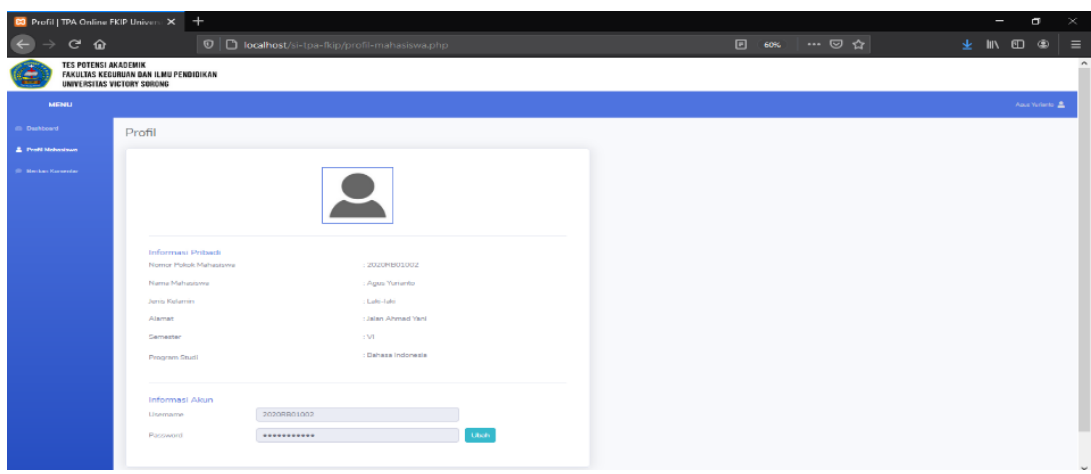

Figure 5. Student Profile Menu

\subsubsection{Test Display}

The display of students taking the exam is the display when the student starts the TPA exam. There are test questions where students can choose an answer. 

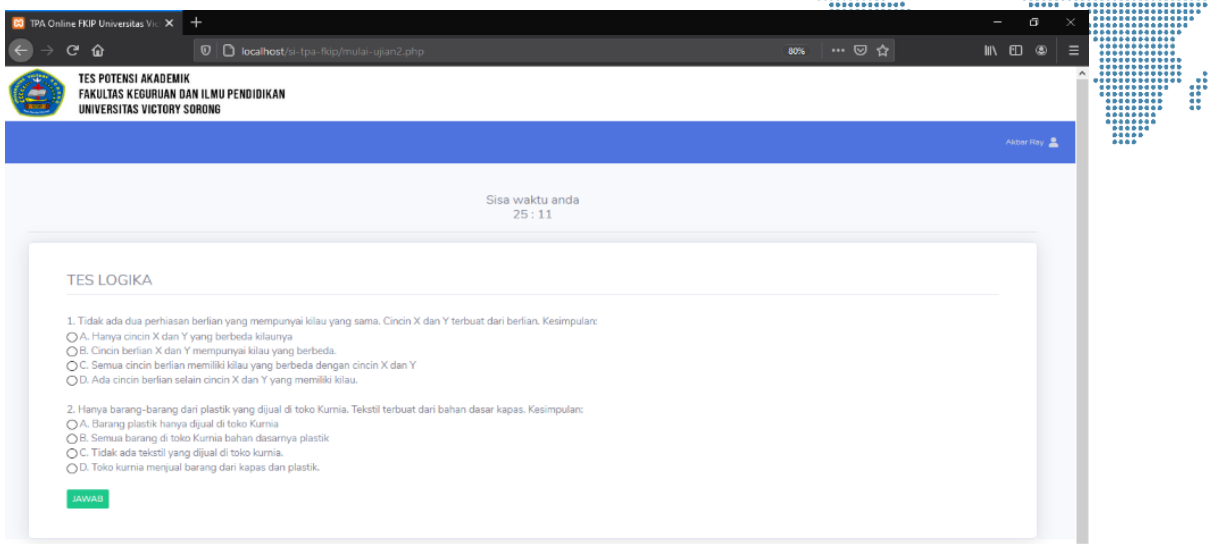

Figure 6. Test Display

\subsubsection{Result Display}

The display of student test results is the display when students have taken this TPA exam. The test results can be seen on this page.

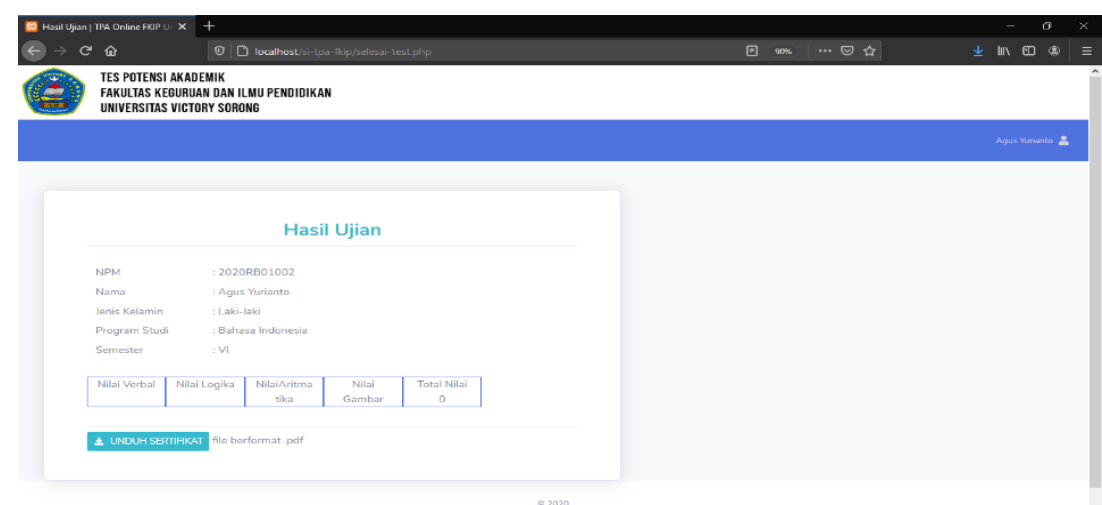

Figure 7. Result Display

\subsection{Admin Display}

\subsubsection{Initial Display}

The main view is the initial view when the system is accessed. Admin can login by filling in the correct username and password in the login form provided.

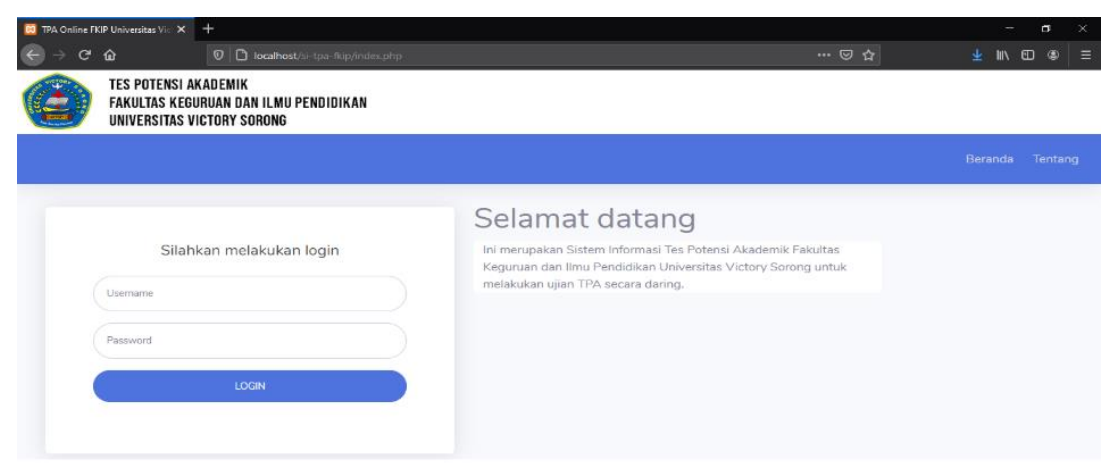

Figure 8. Initial Display 


\subsubsection{Dashboard Menu}

The admin dashboard display is the display when the admin successfully

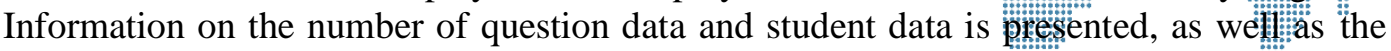
database backup feature.

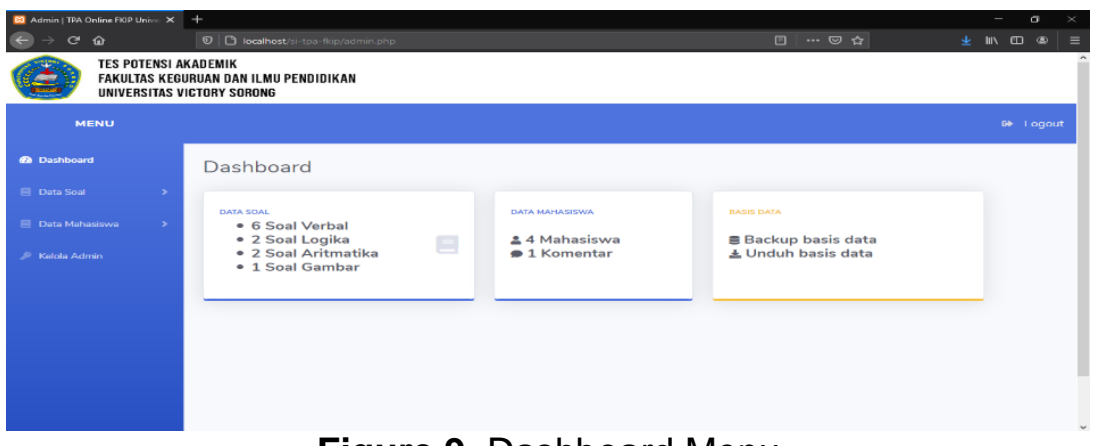

Figure 9. Dashboard Menu

\subsubsection{Student Data Management}

The student data management display is the display when the admin accesses the student data management menu. Presented a table containing student data in the system.

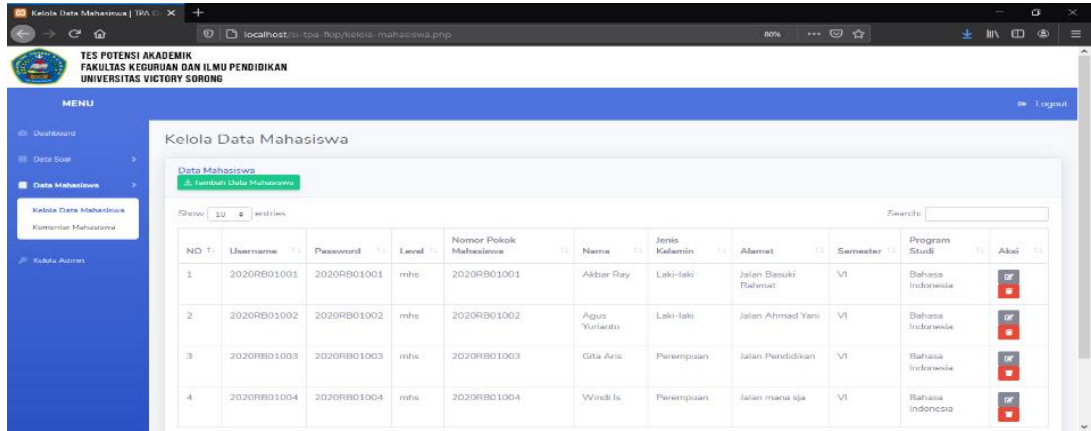

Figure 10. Display of Student Data Management

\subsubsection{Student Input Page}

The student input page is a page that contains a student data input form for admins to add student data into the system.

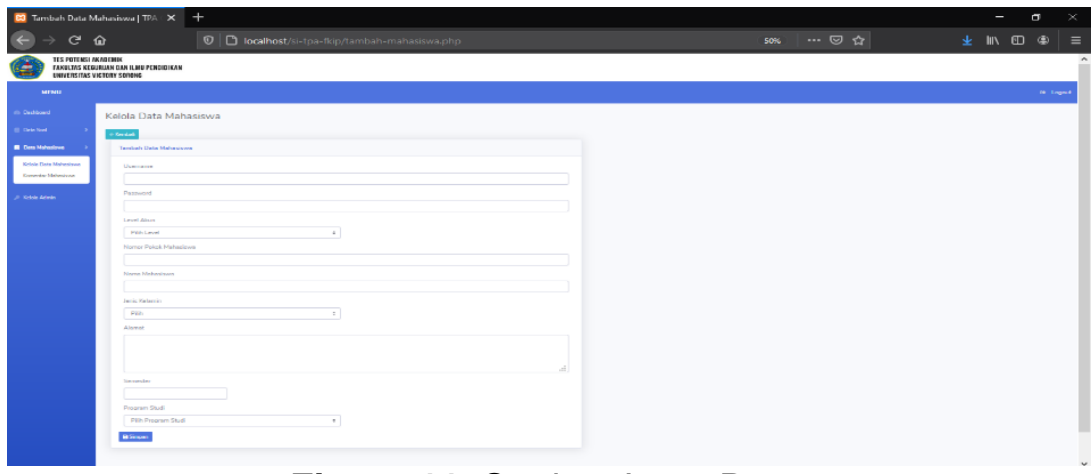

Figure 11. Student Input Page

\subsubsection{Question Data Display}

The question data display is the display when the admin accesses the question data management menu. Presented a table that contains data about the system. 


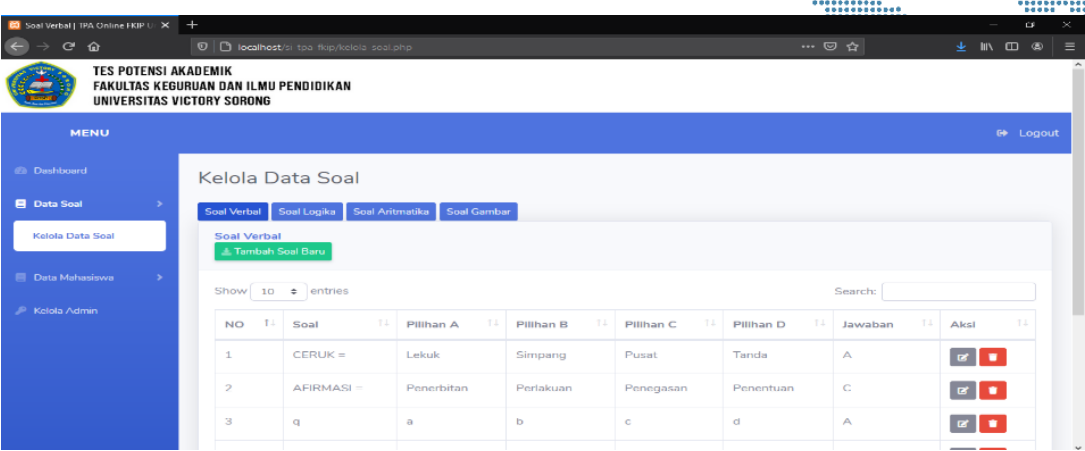

Figure 12. Display of Question Data

\subsubsection{Question Input Page}

The question input page is a page that contains a question input form for admins to add questions to the system.

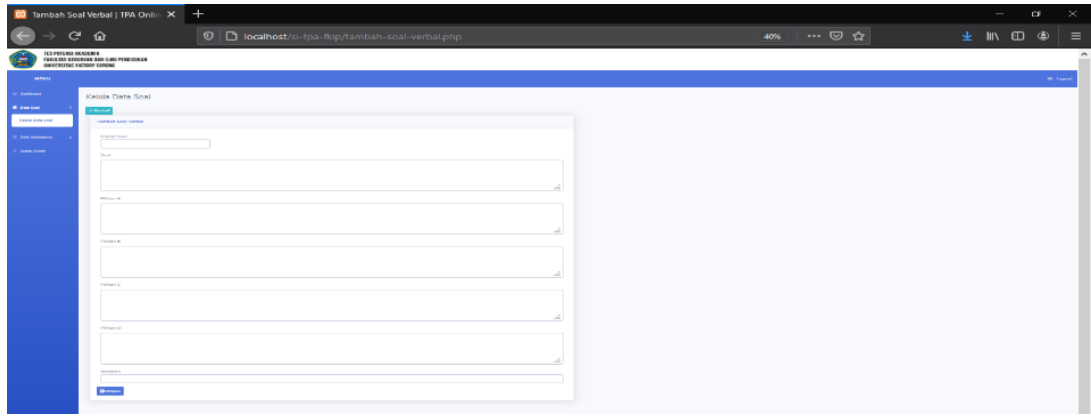

Figure 13. Question Input page

\subsubsection{Manage Admin}

The admin manage view is the view when the admin accesses the Manage admin menu. An admin user info table is presented who can access the system.

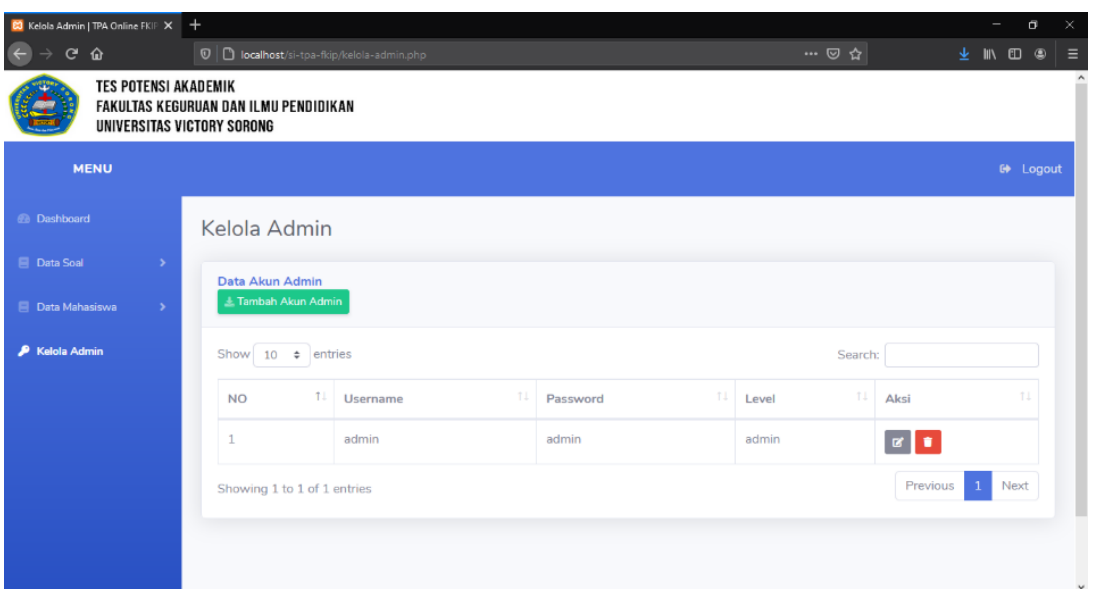

Figure 14. Manage Admin

\subsubsection{Coding Connection}

This image shows the database connection page with the system being built. The server used is localhost with root as the username, and also the name of the database being built is si-tpa-fkip. 


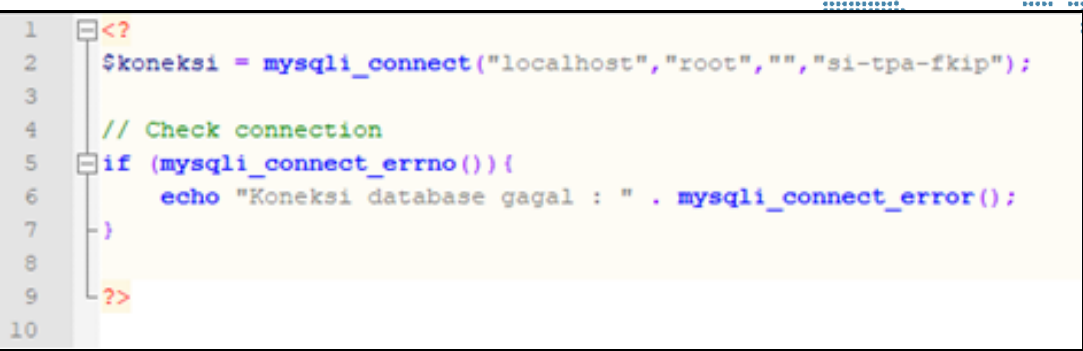

Figure 15. Coding Connection

\section{Conclusion}

Based on the discussion that has been described, the conclusions in this study are:

a) This academic potential test information system will be able to help the Faculty of Teacher Training and Education at Victory University of Sorong in implementing the academic potential test.

b) This academic potential test information system can calculate test scores directly so that the problem of correction time can be resolved.

c) This academic potential test information system can produce a test result certificate in the form of a pdf format file. Thus, students can use the certificate as a condition for participating in the Field Experience Program (PPL).

The process of this information system can be better in the future, it is recommended for further research to input about using excel files and develop this information system into a mobile application version.

\section{References}

[1] Widhiarso, W. (2016). Sekilas Tentang Potensi Akademik. Retrieved June 7, 2018, from http://upap.psikologi.ugm.ac.id/sekilas-tentang-tes-potensi-akademik/

[2] Melda Agnes Manuhutu \& Juneth Wattimena. (2019). Perancangan Sistem Informasi Konsultasi Akademik Berbasis Website. Jurnal Sistem Informasi Bisnis 02 (2019). https://ejournal.undip.ac.id/index.php/jsinbis/article/view/23106/pdf

[3] Riswanto, I. (2013). Pengembangan Soal Tes Potensi Akademik Numerik Penerimaan Siswa Baru Smp Berbantuan Media Berbasis Wireless Application Protocol Java 2 Micro Edition (J2me). Jurnal Pancaran Pendidikan, 2(1), 95-104. Retrieved from http://jurnal.unej.ac.id/index.php/pancaran/article/view/665

[4] Winarti, Muhammad Ihsan, Novita Wulandari. (2020). Perancangan Sistem Informasi Penjualan Berbasis Web Pada Toko Campus Mart Unimuda Sorong Dengan PHP Dan Mysql. Vol 1 No 1 (2020) : Jurnal Petisi (Pendidikan Teknologi Informasi) https://unimuda.e-journal.id/jurnalteknologiinformasi/article/view/390

[5] Sari, A., Ugiarto, M., \& Wati, M. (2017). Sistem Informasi Bimbingan Tugas Akhir Pada Fakultas Ilmu Komputer Dan Teknologi Informasi Universitas Mulawarman. In Prosiding SAKTI (Seminar Ilmu Komputer dan Teknologi Informasi), 2 (1), 242-249.

[6] Sastypratiwi, H., \& Dwiyani, A. (2016). Perancangan Aplikasi Daring Bimbingan Tugas Akhir. Jurnal Edukasi dan Penelitian Informatika (JEPIN), 2(1)

[7] Tuturoong, F. M., Sengkey, R., \& Najoan, X. (2016). Rancang Bangun Sistem Informasi Proses Tugas Akhir. Journal Teknik Informatika, 8(1), 1-6.

[8] Yessy Fadillah, Suprianto. (2017). Sistem Informasi Penjualan Produk Krupuk Berbasis Web Responsive (Studi Kasus : UD. Sumber Makmur). Jurnal Sistem Informasi, Teknologi Informatika dan Komputer Volume 8, Nomor 1 (2017), ISSN 2089-0265. https://jurnal.umj.ac.id/index.php/just-it/article/view/1592.

[9] Sutabri, T., (2016). Sistem Informasi Manajemen (edisi revisi). ANDI, Yogyakarta.

[10] Wibisono dan Susanto., (2015). Perancangan Website Sebagai Media Informasi Dan Promosi Batik Khas Kabupaten Kulonproho. AMIK BSI Yogyakarta Jurnal 
Evolusi, Vol. 3 No. 2, lppm3.bsi.ac.id/jurnalu https://ejournal.bsi.ac.id/ejurnal/index.php/evolusi /article/teview6/521

[11] Sari, R., (2015). Sistem informasi akademik berbasis wob pada SD Nezereri" 29 Jakarta. Jurnal Sistem Informasi STMIK Antar Bangsa, Vộ̣:" 4 No. 2 ISSN 20898711.

[12] Beranda Agency, (2015). MS Access untuk Database Bisnis dan Perkantoran. PT. Elex Media Komputindo. Jakarta.

[13] O'Brien, J. A. (2005). Introduction to information systems, 12th Edition. Torrance, CA: Mc GrawHill College

[14] Adnan Kasim, Lillyan Hadjaratie, Roviana H. Dai. (2020). Rancang Bangun Sistem Informasi Skripsi dan Kerja Praktik Berbasis Web. JAMBURA JOURNAL OF INFORMATICS Vol. 2, No. 2, October 2020 http://ejurnal.ung.ac.id/index.php/jji

\section{Authors}

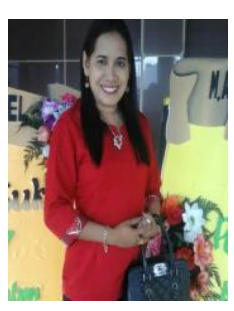

Natasya Virginia Leuwol, is a lecturer of Information System Study Program. She is also the Head of Quality Bureu, Victory University of Sorong

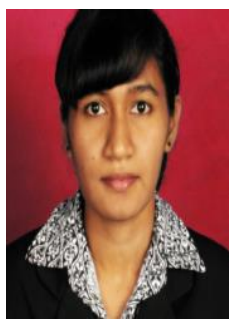

Melda Agnes Manuhutu, is a lecturer of Information System Study Program at Victory University of Sorong

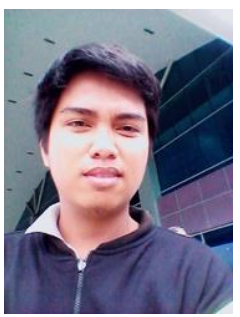

Muhammad Z. Sirajuddin, is a fresh graduate of Information System Study Program at Victory University of Sorong 